\title{
Food Security and coexistence with the semiarid zone in areas affected by drought in the backlands of Pernambuco
}

\author{
Segurança Alimentar e convivência \\ com o semiárido em áreas \\ afetadas pela seca no sertão \\ de Pernambuco
}

\author{
Amanda Tayná Tavares de FIGUEIREDO ${ }^{1}$ iD 0000-0003-1439-5069 \\ Fernanda Cristina de Lima Pinto TAVARES 2 ID 0000-0003-2118-7268

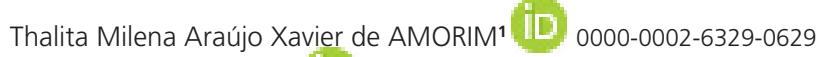 \\ Juliana Souza OLIVEIRA ${ }^{1}$ ID 0000-0003-1449-8930 \\ Vanessa Sá LEAL ${ }^{1}$ iD 0000-0001-9492-2580 \\ Pedro Israel Cabral de LIRA' ID 0000-0002-1534-1620
}

A B S T R A C T

\section{Objective}

Between 2010 and 2017, it was registered one of the most intense droughts in the Brazilian Northeastern Semiarid region, when the rainfall was below the historical level for the region. This context was related to water scarcity for

\footnotetext{
1 Universidade Federal de Pernambuco, Centro de Ciências da Saúde, Programa de Pós-Graduação em Nutrição. Av. Nelson Chaves, Cidade Universitária, 50670-901, Recife, PE, Brasil. Correspondence to: F.C.L.P. TAVARES. E-mail: <fernanda.lpinto@ufpe.br>.

2 Universidade Federal de Pernambuco, Centro de Ciências da Saúde, Departamento de Nutrição. Recife, PE, Brasil. Support: Conselho Nacional Brasileiro de Desenvolvimento Científico e Tecnológico (CNPq, Brazilian National Council for Scientific and Technological Development) (Chamada Universal MCTI/CNPq no 14/2013); Coordenação de Aperfeiçoamento de Pessoal de Nivel Superior (CAPES, Coordination for the Improvement of Higher Education Personnel).

Article elaborated from dissertation by A. T. T. FIGUEIREDO, entitled "Segurança Alimentar e Nutricional e a Convivência com o Semiárido na Percepção de Moradores do Sertão de Pernambuco". Universidade Federal de Pernambuco; 2020.
}

How to cite this article

Figueiredo ATT, Tavares FCLP, Amorim TMAX, Oliveira JS, Leal VS, Lira PIC. Food Security and coexistence with the semiarid zone in areas affected by drought in the backlands of Pernambuco. Título. Rev Nutr. 2021;34:e200299. https://doi.org/10.1590/16789865202134200299 
human consumption and productive activities in this territory, where the semiarid backlands of the state of Pernambuco are located. The objective of this study was to assess the condition of food security and its associated factors in areas affected by drought in the semiarid zone of Pernambuco, Brazil.

\section{Methods}

It was a cross-sectional study on a populational base. Data were collected by socioeconomic and demographic surveys, and the Brazilian Food Insecurity Scale, which were applied to 252 households, from September to October 2015. The data was analyzed by socioeconomic and demographic characterization of the households, and the identification of the food insecurity prevalence and its associated factors, by Poisson regression.

\section{Results}

The prevalence of food insecurity was high (74.6\%). Among those, 9,1\% were on starvation, which means severe insecurity. Food insecurity was statistically associated to sanitation, per capita income, and the number of household residents. Lack of money was the main self-reported cause to food insecurity.

\section{Conclusion}

The high prevalence of food insecurity being associated to indicators of great social vulnerability shows the role of social and economic inequities on the inadequate access to food amongst families in the semiarid zone on a nearly generalized low-income context. These findings corroborate to the evident need of expanding and reinforcing public policies, as well sustainable development models to prioritize and promote social inclusion of communities at greater vulnerabilities in the Brazilian semiarid area. Thus, the need of these economic and social public strategies is highlighted by the worsening of historical vulnerable conditions due to the cycles of droughts on this region.

Keywords: Droughts. Food and Nutrition Security. Public Policy. Regional Development. Semiarid Zone.

\section{RE S U M O}

\section{Objetivo}

Entre 2010 e 2017, foi registrada uma das mais intensas secas do Semiárido Nordestino, com precipitações inferiores ao padrão de referência para a região e com escassez hidrica para consumo humano e para atividades produtivas no território, onde está inserido o Sertão Pernambucano. Este trabalho objetivou avaliar a situação de segurança alimentar e seus fatores associados em áreas afetadas pela seca no sertão de Pernambuco.

\section{Métodos}

Foi realizado um estudo transversal de base populacional, com coleta de dados por questionários socioeconômicos, demográficos e pela Escala Brasileira de Insegurança Alimentar, aplicados em 252 domicílios, de setembro a outubro de 2015. A análise compreendeu a caracterização socioeconômica e demográfica dos domicílios, a identificação da magnitude da insegurança alimentar e a verificação de seus fatores associados por Regressão de Poisson.

\section{Resultados}

A insegurança alimentar expôs elevada prevalência, equivalente a $74,6 \%$, dos quais 9,1\% apresentaram fome, ou seja, insegurança grave. A insegurança foi estatisticamente associada à renda per capita, à quantidade de moradores dos domicilios e ao esgotamento sanitário. A falta de dinheiro foi o principal motivo referido de insegurança.

\section{Conclusão}

Em um cenário de baixa renda quase generalizada, a alta prevalência de insegurança alimentar, associada a marcadores de grande vulnerabilidade social, demonstra a determinação socioeconômica do comprometimento da alimentação entre famílias sertanejas. Os achados deste estudo reforçam a demanda pela ampliação e pelo fortalecimento de politicas públicas e de modelos de desenvolvimento sustentável no semiárido brasileiro, com estratégias que priorizem a inclusão social e econômica de grupos mais vulnerabilizados, sobretudo frente ao potencial de agravamento da situação durante os períodos de seca.

Palavras-chave: Secas. Segurança Alimentar e Nutricional. Políticas Públicas. Desenvolvimento Regional. Zonas Semiáridas.

\section{NTROD U CTION}

Food and Nutritional Security (FNS) consists of the realization of everyone's right to regular and permanent access to food of adequate quality and quantity, without compromising access to other 
fundamental needs, with health-promoting practices, respect for cultural and sustainable diversity in the environmental, social, and economic perspectives. This concept highlights the multiple dimensions intrinsic to the theme and field of FNS, without dissociating them from the Human Right to Adequate Food and Nutrition [1].

In the dimension of access to food, moderate and severe Food Insecurity (FI) had a decline of over $50 \%$ in Brazil between 2004 and 2013. However, during this period, the same factors associated with such levels of insecurity can be observed, with continuity or increase in the intensity of the associations, including the household conditions of being located in the Northern or Northeastern regions, in an urban area without adequate sanitation, with a greater number of residents per bedroom, and a smaller amount of consumer goods. In addition, having a female head of family, or a head of the family who is unemployed, of a different ethnicity than white, over 60 years old, and with a lower educational level were also factors that remained associated with the phenomenon in question, showing the role of socioeconomic inequalities in compromising household food security [2].

Although the aforementioned trend represents a widespread advance in terms of access to food by Brazilian families, the 2017-2018 Family Budget Survey found a rapid and expressive increase in Fl, reaching a prevalence of $36.7 \%$ after being reduced to $22.6 \%$ in 2013 . Still, the persistence of historical regional inequalities was identified, which were verified in the continuity of the highest prevalence of $\mathrm{Fl}$ in the Northern and Northeastern regions, with $57.0 \%$ and $50.3 \%$, respectively, in contrast to $35.2 \%$ as the highest percentage of insecurity among the other regions [3].

The Northeastern region was the region of Brazil which was most affected by the drought that started in 2010, getting worse between 2012 and 2015, which presented itself as the most serious water crisis in the last 50 years [4-6]. Droughts have historically been linked to hunger in the backlands, however, the food problems in the Brazilian semiarid do not result exclusively from these climatic events and are related to social inequities whose Fl manifestations are seen in more vulnerable populations [7-9]. The inequalities in question are reaffirmed by local studies conducted in the Semiarid of the Northeastern region, which diagnosed high magnitudes of $\mathrm{Fl}$, being associated with sociodemographic characteristics indicative of greater social vulnerability, such as larger families, of lower income groups, beneficiaries of the Programa Bolsa Familia (PBF, Family Allowance Program), living in rural areas or quilombo communities, with precarious health conditions and heads of family with a low educational level and a color different from white [10-14].

In parallel with the FNS transformation in Brazil, with the increase in Fl in 2017-2018 after a continuous reduction of this problem, the paradigmatic transition over the Brazilian semiarid continues to change the ways of understanding and acting in the region, moving away from the perspective of combating drought towards coexisting with the territory [3]. In this process, the first perspective explores the image of the unproductive and resource-scarce backlands, with predominant intervention proposals not contextualized to the local reality and of low effectiveness. From another standpoint, the coexistence with the semiarid region admits the environmental characteristics of this area as a diverse and powerful scenario, valuing local knowledge and social technologies to support development strategies and mitigate the damage caused by water crises [15-18].

Considering the recent changes in the national FNS situation, the possibilities of coexistence and the history of socioeconomic vulnerability in the semiarid region, the demand for monitoring and continuous deepening on the socio-territorial dynamics involved in the dietary conditions of the population of the backlands is evident. In addition to this context, the drought that started in 2010 and is still ongoing during the reference year of this study may have acted as a potent aggravating factor for the mentioned 
vulnerabilities. Thus, it was aimed to assess the situation of food security and its associated factors in areas affected by drought in the backlands of Pernambuco.

\section{METHODS}

This is a population-based cross-sectional study. Fieldwork was conducted from September to October 2015, in the cities of Custódia, Serra Talhada, and Belém de São Francisco in the backlands of the state of Pernambuco, randomly selected through probabilistic sampling by cluster, in which the sample unit was the household. For each municipality, approximately 5 census sectors were drawn, distributed in urban and rural areas, whose proportionality applied to the draw was based on the distribution of the population of Pernambuco by area of residence according to the results of the demographic census prior to the collection [19]. To estimate the sample size, we considered the total inhabitants of the backlands of the state and an expected prevalence of $65 \%$ of $\mathrm{Fl}$, which was based on previous findings referring to the situation of FNS in the studied region [12]. Thus, the sample consisted of 252 households, being representative of the population of the backlands of Pernambuco, with a sampling error of $\pm 6 \%$ and a $95 \%$ confidence level.

Semiarid regions are characterized, in general, by little rain and dry climate. The semiarid region of Brazil is made up of 1,262 municipalities distributed in the states of Bahia, Ceará, Maranhão, Minas Gerais, Paraíba, Pernambuco, Rio Grande do Norte, and Piauí, with most of its territory in the Northeastern region [20]. In Pernambuco, this territory corresponds to the state's backlands, formed by 56 municipalities located in the Backlands and São Francisco mesoregions, two of the five Pernambuco mesoregions, which are defined from a geopolitical division of surrounding cities according to their geographic and socioeconomic characteristics. Thus, the population of the semiarid region of Pernambuco is composed of $1,689,583$ inhabitants, representing $18 \%$ of the state population [21].

As for the characterization of the study area, the high social inequality of the municipalities represented in the sample stands out, as assessed by the Gini Index. Still, the City's Human Development Index reveals low development in Custódia (0.594) and medium in Serra Talhada (0.661) and Belém de São Francisco (0.642). When assessing extreme poverty, the percentage of the extremely poor population of Belém de São Francisco (22.24\%) was twice as high as that of Pernambuco (10.71\%). Such vulnerabilities are also seen in the sanitary perspective, in which the proportion of households with bathrooms and running water was $77.63 \%$ in Serra Talhada, 60.59\% in Belém do São Francisco, and 63.53\% in Custódia [19].

Data were collected through the application of socioeconomic and demographic questionnaires and the Escala Brasileira de Insegurança Alimentar (EBIA, Brazilian Food Insecurity Scale), with complementary questions about the family's access to food, which were used in recent Fl analyses in Brazil. The EBIA consists of 14 questions for households with a resident under 18 years old and 8 questions for households without underage family members. The classification of the condition of food security or insecurity at their different levels requires a scoring criterion and different cutoff points depending on the household age composition, in view of the variation in the number of possible answers [3].

The collection was carried out by higher education professionals, selected and trained by professors from the Nutrition Department of the Universidade Federal de Pernambuco (UFPE, Federal University of Pernambuco). The FNS situation of the household was classified according to the EBIA categories, corresponding to food security and 3 levels of insecurity: mild; moderate; and severe. The prevalence of food security (mild, moderate, and severe $\mathrm{Fl}$ and their respective distributions by socioeconomic and demographic factors) was identified. 
The selection of socioeconomic and demographic variables considered the community and household dimensions of the conceptual model of determinants associated with FNS as proposed by Kepple and Segall-Corrêa [22]. Thus, these variables comprised the following characteristics of the households: location (rural or urban area) and territory (conventional or traditional peoples' territories); per capita income by minimum salary range and poverty line; number of residents; presence of internal and external plumbing; water supply source; drinking wastewater treatment; garbage and waste disposal; registration in the PBF; sex, skin color, educational level, occupation, and religion of the head of the family; and food production.

To verify the statistical association between the FI situation and the socioeconomic household conditions, a multivariate analysis was performed using Poisson logistic regression analysis. Initially, all socioeconomic and demographic variables were inserted into a general model, as a set of possible factors associated with Fl. The variables used in the multivariate analysis were those whose $p$-value was less than 0.20 for the set, according to the bivariate analysis using the chi-square test, and which best demonstrated the associations found after the collinearity test. Thus, such explanatory variables were inserted in a final modeling, keeping the variables with a significant $p$ value $(p<0.05)$ or borderline value $(p<0.10)$ and excluding those that lost significance.

Sampling and data analysis were performed with the aid of Epi Info'T 6.04 software (Atlanta, United States). This study was approved by the Research Ethics Committee involving Human Beings at the Health Sciences Center of the UFPE, according to Ordinance no. 466/2012, of the National Health Council, enrolled in the referred committee, CAAE no. 38878814.9. 0000.5208 and opinion n. 897.655.

\section{R E S U L T S}

Food Insecurity was identified in $74.6 \%$ of families. The mild and moderate forms of insecurity were expressed with similar magnitudes, while severe insecurity presented the lowest prevalence. According to the interviewees, the quality of food was considered regular or positive in almost all households and the main reason for $\mathrm{Fl}$ was their lack of money (Table 1).

Table 1 - Household food security situation, food conditions, and access to government programs among families in the backlands of the state of Pernambuco, 2015.

1 of 2

\begin{tabular}{|c|c|c|}
\hline Specifications & $\mathrm{n}$ & $\%$ \\
\hline \multicolumn{3}{|l|}{ Food security classification $(n=252)$} \\
\hline Food security & 64 & 25.4 \\
\hline Food insecurity & 188 & 74.6 \\
\hline Mild & 84 & 33.3 \\
\hline Moderate & 81 & 32.1 \\
\hline Severe & 23 & 9.1 \\
\hline \multicolumn{3}{|l|}{ Self-reported food quality } \\
\hline Very good & 3 & 1.2 \\
\hline Good & 119 & 47.2 \\
\hline Regular & 122 & 48.4 \\
\hline Bad & 5 & 2.0 \\
\hline Very bad & 3 & 1.2 \\
\hline \multicolumn{3}{|l|}{ Self-reported reasons for food insecurity $(n=188)$} \\
\hline Lacked money for food & 164 & 87.2 \\
\hline Lack of variety of the food of my preference at the food outlet & 57 & 30.3 \\
\hline
\end{tabular}


Table 1 - Household food security situation, food conditions, and access to government programs among families in the backlands of the state of Pernambuco, 2015.

2 of 2

\begin{tabular}{|c|c|c|}
\hline Specifications & $\mathrm{n}$ & $\%$ \\
\hline I am/we are in debt, have no credit & 39 & 20.7 \\
\hline There was no gas, firewood, or alcohol to cook & 34 & 18.1 \\
\hline It is exceedingly difficult to get to the market/fair/warehouse/outlet & 32 & 17.0 \\
\hline Lack of sufficient food production to my/our livelihood & 29 & 15.4 \\
\hline There was no water to cook & 15 & 8.0 \\
\hline Health problems prevented me from cooking or eating & 6 & 3.2 \\
\hline Had no time to go shopping or to cook & 5 & 2.7 \\
\hline I am/we are on a special diet & 5 & 2.7 \\
\hline \multicolumn{3}{|l|}{ Participation in government programs $(n=252)$} \\
\hline Families registered in social programs & 173 & 68.7 \\
\hline Families not registered in social programs & 79 & 31.3 \\
\hline \multicolumn{3}{|l|}{ Government programs $(n=173)$} \\
\hline Bolsa Família Programa & 159 & 91.9 \\
\hline Cistern programb & 21 & 12.1 \\
\hline Milk/Food Distribution Program (with the consumer as the main beneficiary) & 17 & 9.8 \\
\hline Others & 16 & 9.2 \\
\hline Food basket (with the consumer as the main beneficiary) ${ }^{c}$ & 4 & 2.3 \\
\hline National Program for Strengthening Family Farming (rural credit) ${ }^{\mathbf{d}}$ & 4 & 2.3 \\
\hline Continuous Cash Benefit Programe & 3 & 1.7 \\
\hline Food Acquisition Program (with the producer as the main beneficiary) ${ }^{c}$ & 2 & 1.2 \\
\hline
\end{tabular}

Note: aFamily Allowance Program: direct income transfer with conditionalities, aimed at families in situations of poverty and extreme poverty; ${ }^{\mathbf{b}}$ National program to support the capture of rainwater and other social technologies for access to water, carried out by municipal governments in partnership with civil society entities; 'Purchasing program by the federal government, aiming to promote access to food and encourage family farming, which provides for the purchase, by the state, of family farmers' production (with the producer as the main beneficiary) to be destined for people in a situation of food and nutritional insecurity (with the consumer as the main beneficiary), including a modality to stimulate milk production and consumption; ${ }^{\mathrm{d}}$ Funding costs and investments aimed at supporting agricultural and non-agricultural activities of family farmers, in order to generate income and qualify family members; ePayment of a monthly minimum salary for elderly and/or disabled people, whose per capita monthly family income is less than $1 / 4$ of the minimum salary [45-47].

The highest prevalence of insecurity was found in households in the rural area and in traditional peoples' territories, headed by women, individuals of brown color, with low educational level, and unemployed or informal workers. The segments in which Fl was more prevalent were also identified among families of lower per capita income and with higher household density, enrolled in the PBF, with some level of food production, with water supply not connected to the public sanitation system, and consuming untreated or domestically treated water (Table 2).

As for the socioeconomic and demographic characteristics of the households, there is an almost generalized situation of low income and a low number of formally employed heads of families. From a sanitary perspective, different vulnerabilities also stand out, comprising $24.6 \%$ of households without internal plumbing, 36\% without being connected to the water supply system, $82.9 \%$ consuming water without treatment or domestically treatment, and $5.6 \%$ with open-air sumps (Table 2).

In addition to the PBF, the other social programs found in the population studied were viewed in small proportions and corresponded to the Benefício de Prestação Continuada (Continuous Cash Benefit), construction of cisterns, initiatives to support family farming, and different segments of institutional food purchase (Table 1). 
Table 2 - Characterization of the sample and distribution of food security situation according to the socioeconomic and demographic characteristics of households in the backlands of the state of Pernambuco, 2015.

1 of 2

\begin{tabular}{|c|c|c|c|c|c|c|c|c|}
\hline \multirow{3}{*}{$\begin{array}{l}\text { Socioeconomic and demographic characteristics of } \\
\text { the household }\end{array}$} & \multicolumn{8}{|c|}{ Food security situation } \\
\hline & \multicolumn{2}{|c|}{ Total $^{\mathrm{a}}$} & \multicolumn{2}{|c|}{ Food security } & \multicolumn{2}{|c|}{ Mild Fl ${ }^{\mathbf{b}}$} & \multicolumn{2}{|c|}{ Moderate or severe F } \\
\hline & $n=252$ & $\%$ & $n=64$ & $\%$ & $n=84$ & $\%$ & $\mathrm{n}=104$ & $\%$ \\
\hline \multicolumn{9}{|l|}{ Situation $^{1}$} \\
\hline Urban & 140 & 56.0 & 48 & 34.3 & 47 & 33.6 & 45 & 32.1 \\
\hline Rural & 110 & 44.0 & 15 & 13.6 & 37 & 33.6 & 58 & 52.7 \\
\hline \multicolumn{9}{|l|}{ Territory $^{1}$} \\
\hline Conventional & 218 & 86.5 & 63 & 28.9 & 67 & 30.7 & 88 & 40.4 \\
\hline Quilombo/ Settlement ${ }^{c}$ & 34 & 13.5 & 1 & 2.9 & 17 & 50.0 & 16 & 47.1 \\
\hline \multicolumn{9}{|l|}{ Color of the head of the family ${ }^{1}$} \\
\hline White & 58 & 23.0 & 23 & 39.7 & 16 & 27.6 & 16 & 32.8 \\
\hline Brown/Black/Yellow/Indigenous ${ }^{\mathbf{d}}$ & 193 & 77.0 & 41 & 21.2 & 67 & 34.7 & 85 & 44.0 \\
\hline \multicolumn{9}{|l|}{ Sex of the head of the family ${ }^{1}$} \\
\hline Male & 187 & 74.5 & 51 & 27.3 & 65 & 34.8 & 71 & 49.7 \\
\hline Female & 64 & & 13 & 20.3 & 18 & 28.1 & 33 & 51.6 \\
\hline \multicolumn{9}{|l|}{ Educational level of the head of the family (years) ${ }^{1}$} \\
\hline Up to 4 years/Do not know & 108 & 43.0 & 22 & 20.4 & 40 & 37.0 & 46 & 42.6 \\
\hline Between 5 and 8 years & 71 & 28.3 & 18 & 25.4 & 18 & 25.4 & 35 & 49.3 \\
\hline 9 or more years & 72 & 28.7 & 24 & 33.3 & 25 & 34.7 & 23 & 31.9 \\
\hline \multicolumn{9}{|l|}{ Occupation of the head of the family ${ }^{1}$} \\
\hline Legal worker & 39 & 15.5 & 13 & 33.3 & 17 & 43.6 & 9 & 23.1 \\
\hline Retired/ Beneficiary of social program/ Pensioner & 47 & 18.7 & 20 & 42.6 & 12 & 25.5 & 15 & 31.9 \\
\hline Self-employed(urban or rural) & 52 & 20.7 & 13 & 25.0 & 18 & 34.6 & 21 & 40.4 \\
\hline Informal worker & 84 & 33.5 & 13 & 15.5 & 23 & 27.4 & 48 & 57.1 \\
\hline Does not work/ Unemployed & 29 & 11.6 & 5 & 17.2 & 13 & 44.8 & 11 & 37.9 \\
\hline \multicolumn{9}{|l|}{ Per capita income $e^{\mathbf{e}, 1}$} \\
\hline Up to $1 / 4$ minimum salary & 124 & 50 & 17 & 13.7 & 42 & 33.9 & 65 & 52.4 \\
\hline Between $1 / 4$ and $1 / 2$ minimum salary & 77 & 31.0 & 21 & 27.3 & 31 & 40.3 & 25 & 32.5 \\
\hline More than $1 / 2$ minimum salary & 47 & 18.9 & 26 & 55.3 & 9 & 19.1 & 12 & 25.5 \\
\hline \multicolumn{9}{|l|}{ Per capita income $\mathrm{f}^{\mathrm{f}} \mathbf{1}$} \\
\hline Extreme poverty/ Poverty & 89 & 35.9 & 91 & 10.1 & 27 & 30.3 & 53 & 59.6 \\
\hline Above poverty & 159 & 64.1 & 55 & 34.6 & 55 & 34.6 & 49 & 30.8 \\
\hline \multicolumn{9}{|l|}{ Bolsa Família Program ${ }^{1}$} \\
\hline Family enrolled & 159 & 63.1 & 29 & 18.2 & 51 & 32.1 & 79 & 49.7 \\
\hline Family not enrolled & 93 & 36.9 & 35 & 37.6 & 33 & 35.5 & 25 & 26.9 \\
\hline \multicolumn{9}{|l|}{ Number of household residents ${ }^{1}$} \\
\hline Up to 3 residents & 85 & 33.7 & 28 & 32.9 & 30 & 35.3 & 27 & 31.8 \\
\hline 4 residents & 73 & 29.0 & 22 & 30.1 & 21 & 28.8 & 30 & 41.1 \\
\hline 5 or more residents & 94 & 37.3 & 14 & 14.9 & 33 & 35.1 & 47 & 50 \\
\hline \multicolumn{9}{|l|}{ Production of food ${ }^{2}$} \\
\hline Plants and/or animals & 63 & 25.0 & 13 & 20.6 & 28 & 44.4 & 22 & 34.9 \\
\hline Does not plant and does not have animals & 189 & 75.0 & 51 & 27.0 & 56 & 29.6 & 82 & 43.4 \\
\hline \multicolumn{9}{|l|}{ Access to piped water ${ }^{2}$} \\
\hline Plumbing within the household & 190 & 75.4 & 53 & 27.9 & 56 & 29.5 & 81 & 42.6 \\
\hline Plumbing until the front yard/No access & 62 & 24.6 & 11 & 17.7 & 28 & 45.2 & 23 & 37.1 \\
\hline \multicolumn{9}{|l|}{ Water supply ${ }^{1}$} \\
\hline Main supply system & 159 & 63.1 & 49 & 30.8 & 49 & 30.8 & 61 & 38.4 \\
\hline Cistern/Well/Others & 93 & 36.9 & 15 & 16.1 & 35 & 37.6 & 43 & 46.2 \\
\hline Drinking water ${ }^{3}$ & & & & & & & & \\
\hline Boiled/Filtered/Mineral & 113 & 44.8 & 32 & 28.3 & 35 & 31.0 & 46 & 40.7 \\
\hline Strained/Untreated/Other & 139 & 55.2 & 32 & 23.0 & 49 & 35.3 & 58 & 41.7 \\
\hline
\end{tabular}


Table 2 - Characterization of the sample and distribution of food security situation according to the socioeconomic and demographic characteristics of households in the backlands of the state of Pernambuco, 2015.

2 of 2

\begin{tabular}{|c|c|c|c|c|c|c|c|c|}
\hline \multirow{3}{*}{$\begin{array}{l}\text { Socioeconomic and demographic characteristics of } \\
\text { the household }\end{array}$} & \multicolumn{8}{|c|}{ Food security situation } \\
\hline & \multicolumn{2}{|c|}{ Total $^{a}$} & \multicolumn{2}{|c|}{ Food security } & \multicolumn{2}{|c|}{ Mild Fl ${ }^{\mathbf{b}}$} & \multicolumn{2}{|c|}{ Moderate or severe $\mathrm{FI}$} \\
\hline & $n=252$ & $\%$ & $n=64$ & $\%$ & $n=84$ & $\%$ & $n=104$ & $\%$ \\
\hline \multicolumn{9}{|l|}{ Wastewater destination $^{1}$} \\
\hline Public sanitation system & 157 & 75.4 & 55 & 35.0 & 48 & 30.6 & 54 & 34.4 \\
\hline Sump/Water streams/Others/Do not know & 95 & 24.6 & 9 & 9.5 & 36 & 37.9 & 50 & 52.6 \\
\hline
\end{tabular}

Note: ${ }^{a}$ Data column referring to the characterization of the sample. Variables with an $\mathrm{n}$-value below the total due to the absence of data ${ }^{\mathbf{b}} \mathrm{Fl}$ : Food insecurity; 'Settlement: $n=1 ; \%=0.4$; ${ }^{\text {Brown: }} n=172$; Black: $n=16$; Yellow: $n=4$; Indigenous: $n=1$; ${ }^{e}$ Minimum Salary: BRL=788.00; USD=235.93; ${ }^{\mathbf{f}}$ Classification criteria by the Ministry of Social Development in the implementation of the Bolsa Familia Program in 2015: Extreme Poverty: Per capita income <77.00; Poverty: Per capita income $77-154.00 ;{ }^{1}$ Chi-square: $p<0.05 ;{ }^{2}$ Chi-square: $p<0.10 ;{ }^{3}$ Chi-Square: $p<0.20$.

In the model resulting from the multivariate analysis, FI was statistically associated with household density, per capita income, and waste disposal, indicating respectively greater vulnerability to compromised access to food for poor or extremely poor families, with 5 or more household residents, and not connected to the public sanitation system (Table 3).

Table 3 - Prevalence ratio of food insecurity and socioeconomic factors in households in the backlands of the state of Pernambuco, 2015.

\begin{tabular}{|c|c|c|c|c|c|c|c|c|}
\hline \multirow{2}{*}{ Variables } & \multirow{2}{*}{$\begin{array}{c}\text { Total } \\
n=252\end{array}$} & \multicolumn{2}{|c|}{$\mathrm{Fl}^{\mathrm{a}}$} & \multicolumn{5}{|c|}{ Prevalence Ratios $^{\mathbf{b}}$ of $\mathrm{Fl}$} \\
\hline & & $\mathrm{n}$ & $\%$ & Gross PR & $\mathrm{Cl} 95 \%{ }^{c}$ & Adjusted PR & $\mathrm{C} 195 \%$ & $p$-value \\
\hline \multicolumn{9}{|l|}{ Territory } \\
\hline Conventional & 218 & 155 & 71.1 & 1.0 & & 1.0 & & \multirow[t]{2}{*}{0.068} \\
\hline Quilombo/Settlement & 34 & 33 & 97.1 & 1.36 & $1.23-1.51$ & 1.13 & $0.99-1.28$ & \\
\hline \multicolumn{9}{|l|}{ Color of the head of the family } \\
\hline White & 58 & 32 & 60.4 & 1.0 & & 1.0 & & \multirow[t]{2}{*}{0.095} \\
\hline Brown/ Black/ Yellow/ Indigenous & 193 & 152 & 78.7 & 1.30 & $1.05-1.63$ & 1.19 & $0.97-1.47$ & \\
\hline \multicolumn{9}{|l|}{ Per capita income ${ }^{\mathbf{d}}$} \\
\hline$>$ Poverty line & 159 & 104 & 65.4 & 1.0 & & 1.0 & & \multirow[t]{2}{*}{0.001} \\
\hline$\leq$ Poverty line & 89 & 80 & 89.9 & 1.37 & $1.20-1.57$ & 1.25 & $1.10-1.37$ & \\
\hline \multicolumn{9}{|l|}{ Number of household residents } \\
\hline Up to 4 residents & 158 & 108 & 68.4 & 1.0 & & 1.0 & & \multirow[t]{2}{*}{0.009} \\
\hline 5 or more residents & 94 & 80 & 85.1 & 1.24 & $1.09-1.43$ & 1.19 & $1.04-1.36$ & \\
\hline \multicolumn{9}{|l|}{ Wastewater destination } \\
\hline Public sanitation system & 157 & 102 & 65.0 & 1.0 & & 1.0 & & \multirow{2}{*}{0.003} \\
\hline Sump/ Water streams/ Others/ Do not know & 95 & 86 & 90.5 & 1.39 & $1.22-1.59$ & 1.25 & $1.08-1.45$ & \\
\hline
\end{tabular}

Note: ${ }^{\text {a }}$ I: Food Insecurity (mild+moderate + severe); ${ }^{b}$ Poisson Regression Analysis, PR: Prevalence Ratio. ${ }^{\mathrm{c}} \mathrm{Cl} 95 \%$ Confidence Interval. ${ }^{\mathrm{d}} \mathrm{Classification}$ criteria of the Ministry of Social Development in the implementation of the Bolsa Familia Program in 2015: Extreme Poverty <BRL 77.00; Poverty $\geq B R L$ 77.00 and <154.00; Above the poverty line> BRL 154.00 (per capita/month). Adjustment variables that were excluded from the final model ( $p<0.20)$ : area (rural or urban location); per capita income (minimum salary bracket); enrollment in the Bolsa Familia Program; individual's sex; individual's educational level; individual's occupation; and food production.

\section{DISCUSSION}

The prevalence of $\mathrm{Fl}$ in the present study was much higher than in 2013 , with $22.6 \%$ of families suffering with $\mathrm{Fl}$ in Brazil, and $38.1 \%$ of families in the Northeastern region. When considering the 2017-2018 data, with 34.9\% of Brazilian households and $50.3 \%$ of Northeasterners suffering $\mathrm{Fl}$, such 
prevalences are also surpassed by the highlighted result [3]. This finding also represented a higher prevalence in relation to a $\mathrm{Fl}$ of $68.4 \%$ in 2015 and $65.8 \%$ in the backlands of the state of Pernambuco in 2010 and 2011. In addition, the prevalence of $\mathrm{Fl}$ found in this study exceeded the Fl prevalence dimension in other territories of the Brazilian semiarid region, as observed in $65 \%$ of the population investigated in the city of Queimadas, 69.2\% in Campina Grande, and 55.6\% in Cuité [9-13,23,24].

Per capita income, household density, and waste disposal, associated with Fl, elucidate the permanence of a framework of social determination marked by socioeconomic inequities in access to adequate and healthy food for the population of the Brazilian semiarid region. The association between poor/extremely poor families and Fl was consistent to the low income of this population group, being the most cited reason for $\mathrm{Fl}$, and to the expressive coverage of the PBF, since combating hunger and immediate poverty relief is one of the main objectives of the program.

The relationship between social indicators and the household Fl experience is evidenced in different population groups. Based on a systematic review, Lignani et al. [25] identified per capita income and sanitation as social indicators directly related to $\mathrm{Fl}$, while the number of household residents had an indirect and income-mediated relationship. Covering a period of drought in the semiarid region of the state of Paraiba, there was a strong influence of income and access to PBF in determining FI in the households of the city of Cuité, among other associated factors, such as being in the rural area, not having their own land or retired residents, producing food for self-consumption, and participating in emergency income programs [23].

When analyzing income patterns related to $\mathrm{Fl}$ in the Northeastern and Southern regions of Brazil, Fachinni et al. [26] found that per capita family income is the most important determinant of such phenomenon, being strongly associated with other variables in the occurrence of moderate and severe insecurity. In the aforementioned study, the linear decrease in the most severe levels of insecurity was verified as the per capita income of families increased, allowing the projection of the value of BRL 174.00 of minimum income per person for the reduction in $59.5 \%$ of the magnitude of the $\mathrm{Fl}$ in the Northeastern region [26].

When comparing household income extremes, the 2017-2018 Family Budget Survey showed a trend of an increasing proportional expenditure on food in the lower income groups, in which $79.4 \%$ of all household expenses were allocated to the purchase of food, in contrast to $49.7 \%$ for the classes with the highest incomes. The inequality in question was also seen in food expenditures expressed in BRL, as higher income households spent more than three times the national average and six times more than families in the lowest income brackets [27].

The strong association between $\mathrm{Fl}$ and per capita income (poverty or extreme poverty) highlights the role of the extremely unequal income distribution in Brazil in compromising food in the household. In this way, the relevance of social and income transfer policies for the reduction of this problem among vulnerable groups is evident, highlighting the need for greater effectiveness and equity, as well as the importance of including these issues at the center of discussions about the possible implementation of a universal basic income. In addition, the high prevalence of $\mathrm{Fl}$ associated with the income condition in the Brazilian semiarid region reflects the consequences of a development model without social inclusion and territorially out of context.

As for the association between having 5 or more residents per household and $\mathrm{Fl}$, this finding can be attributed to a disproportional increase in the size of families in relation to the increase in their income for a greater acquisition of food, as considered by Anschau et al. [28] based on the identification of larger families as a factor associated with FI among PBF beneficiaries [28,29]. In an analysis referring to the years 
2017 and 2018, Brazilian households with 3 or more residents had a higher prevalence of Fl compared to less populated households. The association between compromising food and having larger families was also found in semiarid territories in the state of Paraíba and in rural communities in the state of Bahia $[2,3,11,14]$.

Despite the tendency to reduce the size of Brazilian families, it appears that the predominant household density in this study was higher than the national average of 3 residents for the year investigated, confirming regional differences. In this perspective, the Northern and Northeastern regions lead the rates of households with more residents, mainly in rural areas, in addition to presenting higher proportions of excessive household density in relation to the Southern and Midwestern regions [30]. The different strata of the number of abovementioned residents reinforce the presence of socioeconomic vulnerabilities in the semiarid population, presenting this region not only as a scenario of a predominant condition of $\mathrm{Fl}$ associated with more numerous households, but as a space of social and family structure that is distant from the Brazilian average.

Observing the studied sanitation conditions, the strong association of FI with wastewater disposal carried out by means other than the public sanitation system demonstrates the precarious health conditions as indicators of socially vulnerable populations. Corroborating this finding, according to Santos et al. [2], the lack of basic sanitation corresponded to a factor associated with the greatest severity of FI in urban households in Brazil, given the observed tendency to reduce this phenomenon between 2003 and 2014.

At the local level, the presence of open sewage was associated with insecurity among households in a municipality in the semiarid region of Paraiba. Along with the aforementioned associations, the verification of the type of sanitation system as a factor associated with $\mathrm{Fl}$ is also corroborated by other sanitary conditions associated with compromising the families' access to food, as seen in different areas of the Northeastern region, among which is the consumption of untreated water and the absence of a bathroom $[10,11,31]$. Reiterating the sanitary characteristics as a product of the vulnerability of the investigated territory, the $63 \%$ of the studied families connected to the public water supply system contrasts with the $85.4 \%$ coverage of this service in Brazil [30]. The referred situations reflect the persistence of structural difficulties related to access to water and basic sanitation services in the Brazilian semiarid region.

Although the territory and skin color of the head of the household were not identified as factors associated with $\mathrm{Fl}$, the 'p-value' of these variables showed a borderline result for the indication of a statistically significant association. In view of this finding, it is worth mentioning almost all families suffered with $\mathrm{Fl}$ in quilombo households, since the territorial and ethnic conditions of socially vulnerable populations are related to the non-accomplishment of FNS due to access to food $[2,9-11,16,27,28,32,33]$.

Regarding agricultural activities, the highest proportion of $\mathrm{Fl}$ among food-producing families stands out, however, with moderate and severe levels of insecurity, the highest proportions were among households without food production. The high prevalence of insecurity in these families allows us to emphasize that producing food does not mean that this family does not suffer with Fl, especially in a context of a worsening drought with great losses in productive areas of the backlands [4,5]. Despite this, the production of food, especially for self-consumption, may have reduced the intensity of dietary restrictions in the households and communities in which they were developed. In the semiarid region of the state of Ceará, rural families were twice as likely to experience FI compared to urban households, however, a lower risk of insecurity was seen in the rural population when considering only the most serious cases, assuming that subsistence agriculture and local solidarity could play a role in the reduction of severe $\mathrm{Fl}$ in rural areas [13].

Reiterating the aforementioned local findings, after a severe drought in South Africa, it was identified that rural households of low socioeconomic status were less likely to experience Fl compared to their urban peers, a result attributed to the possible access of agricultural families to natural resources and land [34]. 
The relationship between income and food for the rural population was also seen in Sub-Saharan Africa from the perception of farmers about the impacts of drought on the FI of their households, where those who did not feel its impacts had the highest incomes among the investigated group, showing different layers of vulnerability in an agricultural production scenario during a drought in a semiarid climate [35].

In addition to the weaknesses related to FNS in rural areas due to water scarcity, the low expressiveness of the Programa Nacional de Fortalecimento da Agricultura Familiar (PRONAF, National Program for Strengthening Family Agriculture) and the Programa de Aquisição de Alimentos (PAA, Food Acquisition Program), among the government programs accessed by these families, occurs in a context of relevant budget cuts in the PAA, whose 2015 budget was 51\% lower than their budget in 2012, the year in which the investments in the program started to decrease, and may have had a negative impact on the reduction of $\mathrm{Fl}$, since initiatives such as the 'Milk for All' program and the food distribution actions are part of the aforementioned programs and contribute to the generation of income in the local economy [36].

Such programs play a strategic role in implementing FNS and in advancing the paradigm of coexistence with the semiarid, while strengthening small producers, through the generation of income by creating a regular demand for their production, and assisting vulnerable families, donating this production to them. Thus, the permanence of populations in the semiarid environment is encouraged by the association of locally contextualized agricultural practices with emergency actions in the face of compromised food and socioeconomic issues in the Northeastern backlands [17,18,37-39].

In addition to programs with an emphasis on family farming, from 2015 onwards there was a greater intensity in the weakening of public policies, including actions directed to the area of food and nutrition. In this trajectory, Constitutional Amendment 95/2016 limited public investments for 20 years, imposing restrictions on the financing of health, education, and social protection policies. Subsequently, Provisional Measure 870/2019 extinguished the National Food Security Council, which acted in the formulation and implementation of fundamental strategies for the reduction of $\mathrm{Fl}$ in Brazil and in the elaboration of the Living in the Semiarid Region Programs [40-42].

In keeping with the relative success of initiatives oriented towards living with the semiarid region, the reduction of the dependence of backland families on access to water and the encouragement for sustainable food production, which is still not enough to lift this historically vulnerable population from poverty, it is observed that the phenomenon of $\mathrm{Fl}$ in the midst of drought remains conditioned to socio-political structures that precede the scarcity of water in this territory [43]. From an environmental and humanitarian perspective, Sandstrom and Juhola [44] identified the predominance of documentary narratives in which the absence of rain is placed as the main cause of food insecurity in African regions affected by droughts, highlighting the urgency for approaches to overcome this emphasis and consider the complexity of these phenomena in their social and political contexts.

In this sense, the conditions of access to food identified in the period of drought, which started in 2010 and still ongoing in 2015, reiterate the need to fight hunger in the Northeastern backlands, with the recognition of such phenomenon as a regional development problem with social and human roots, as defended by Josué de Castro [7]. In this perspective, as hunger outbreaks in periods of drought over the last centuries should not be treated by coping with the drought itself, the high prevalence of $\mathrm{FI}$ in the contemporary semiarid region should be faced with the planning of regional development in an environmentally, economically, and socially sustainable way, with an emphasis on the generation of jobs and strengthening of public policies aimed at reducing social inequalities and valuing local potential, such as it is traditional backland agriculture. 


\section{CONCLUSION}

The diagnosis of the high prevalence of $\mathrm{Fl}$ associated with great socioeconomic vulnerability markers in the semiarid region of Pernambuco demonstrates that the situation of historically present social inequities in the backlands is still an issue, even though they are manifested in new formats by a process of social reorganization of this territory.

The worsening of the economic and political crisis in the country, in parallel with the phenomenon of Fl in the backlands of the state of Pernambuco in 2015, potentially intensified by the drought in this period, may have played an important role in the food security situation diagnosed in this study, as well as in a greater impact of restrictions after the mentioned period, mainly due to the weakening of social protection policies.

The contrast between the coverage of the PBF and of programs aimed at coexisting with the semiarid in the face of the Fl scenario in question points to the demand for processes of valorization and assessment of public policies in a territorialized and micropolitical way, with the incorporation of semiarid region specificities for a greater effectiveness, inserted in a model of sustainable and inclusive regional development. In addition, the need for future investigations for the monitoring of FNS in the semiarid region is evident, with studies aimed at more vulnerable populations, regarding Fl, in this region, such as traditional peoples' territories and rural communities.

\section{CONTRIBUTORS}

ATT Figueiredo: data collection, analysis, and interpretation; writing and reviewing the manuscript. FCLP Tavares: study conception and design and reviewing and approving the final version; TMAX Amorim: reviewing and approving the final version of the manuscript. JS Oliveira: data interpretation; reviewing and approving the final version of the manuscript. VS Leal: study conception and design; PIC Lira: Data analysis and interpretation; reviewing and approving the final version of the manuscript.

\section{REFERENCES}

1. Guerra LDS, Cervato-Mancuso AM, Bezerra ACD. Alimentação: um direito humano em disputa: focos temáticos para compreensão e atuação em segurança alimentar e nutricional. Ciênc Saúde Coletiva. 2019;24:3369-94. https:// doi.org/10.1590/1413-81232018249.20302017

2. Santos TG, Silveira JAC, Longo-Silva G, Ramires EKNM, Menezes RCE. Tendência e fatores associados à insegurança alimentar no Brasil: Pesquisa Nacional por Amostra de Domicílios 2004, 2009 e 2013. Cad Saúde Pública. 2018;34:e00066917. https://doi.org/10.1590/0102-311x00066917

3. Instituto Brasileiro de Geografia e Estatística. Pesquisa de Orçamentos Familiares 2017-2018: Análise da Segurança Alimentar no Brasil. Rio de Janeiro: Instituto; 2020 [cited 9 Mar 2021]. Available from: https://biblioteca.ibge.gov.br/ visualizacao/livros/liv101749.pdf

4. Confederação Nacional de Municípios (Brasil). Prejuízos causados por desastres naturais, 2012 a 2015: Relatório do Sistema Integrado de Informações sobre Desastres. Brasília: CNM; 2015 [cited 9 Mar 2021]. Available from: https:// www.cnm.org.br/biblioteca/exibe/2473

5. Aquino JR, Nascimento CA. A grande seca e as fontes de ocupação e renda das famílias rurais no nordeste do Brasil. Rev Econ NE. 2020 [cited 9 Mar 2021];51:81-97. https://www.bnb.gov.br/documents/80223/8053916/1090.pdf/ f82903d5-0974-89d4-7056-52e1c927c53b

6. Gondim J, Fioreze AP, Alves RFF, Souza WG. A seca atual no Semiárido nordestino: impactos sobre os recursos hídricos. Parc Estrat 2017 [cited 9 Mar 2021];22:277-300. http://seer.cgee.org.br/index.php/parcerias_estrategicas/ article/view/856 
7. Castro, J. Geografia da Fome (1946). 14a. ed. Rio de Janeiro: Civilização Brasileira; 2002.

8. Silva ÂM, Oliveira JV. A fome na narrativa do semiárido das secas e o direito ao desenvolvimento. Redes. 2019;24:14361. https://doi.org/10.17058/redes.v24i2.13002

9. Monteiro CA, Conde WL, Konno SC. Análise do inquérito chamada nutricional 2005. Cadernos de Estudos: Desenvolvimento Social em Debate. 2006;4:29-36. Available from: https://aplicacoes.mds.gov.br/sagirmps/ ferramentas/docs/caderno\%20-\%2004.pdf

10. Figueroa-Pedraza D, Alves-Bezerra T, Rocha ACD, Fonseca JS. (In)Segurança alimentar de famílias residentes em um município do interior da Paraíba, Brasil. Rev Salud Pública. 2017;19:649-56. https://doi.org/10.15446/rsap. V19n5.39467

11. Pedraza DF, Gama JSFA. Segurança alimentar e nutricional de famílias com crianças menores de cinco anos do município de Campina Grande, Paraíba. Rev Bras Epidemiol. 2015;18:906-17. https://doi.org/10.1590/19805497201500040018

12. Pinto FCL. Segurança alimentar e nutricional no estado de Pernambuco: situação e análise de fatores geográficos e socioeconômicos associados. [Tese]. Recife: Universidade Federal de Pernambuco; 2012.

13. Rocha BEM, Lima RT, Almeida PA. Insegurança alimentar relacionada à área de residência em município do Semiárido brasileiro. Cad Saúde Coletiva. 2014;22:205-11. https://doi.org/10.1590/1414-462X201400020015

14. Silva EKP, Medeiros DS, Martins PC, Sousa LA, Rêgo MAS, Silva TO, et al. Insegurança alimentar em comunidades rurais no Nordeste brasileiro: faz diferença ser quilombola? Cad Saúde Pública. 2017;33(4):e00005716. https://doi. org/10.1590/0102-311x00005716

15. Santos APS, Cunha ARFA, Denis AAC, Perez-Marin AM [org]. Vivências e práticas para coabitação no semiárido brasileiro: ensaios e reflexões. Saber Fazer em Diálogo. Campina Grande: Instituto Nacional do Semiárido; 2016 [cited 9 Mar 2021]. Available from: https://portal.insa.gov.br/acervo-livros/462-vivencias-e-praticas-de-coabitacaono-semiarido-brasileiro-ensaios-e-reflexoes

16. Cassimiro CAL, Oliveira Filho FS, Pereira Junior EB, Feitosa SS, Siqueira EC. Convivência com o semiárido: interação social, ambiental e tecnológica com a Caatinga. RAF. 2020;13:28-40. https://doi.org/10.18542/raf.v13i1.6783

17. Nascimento IRT, Gomes C, Brasil AA. Convivência com o Semiárido como Imperativo para a Sustentabilidade e seus Desafios no Contexto dos Objetivos de Desenvolvimento Sustentável (ODS). Sust Deb. 2016;7:239-43. https://doi. org/10.18472/SustDeb.v7nEsp.2016.21523

18. Gentile C, Burgos A. Coopercuc: percursos de valorização dos recursos locais e de convivência com o Semiárido. Sustent Deb. 2016;7:136-51. https://doi.org/10.18472/SustDeb.v7n0.2016.18321

19. Instituto Brasileiro de Geografia e Estatística. Censo Demográfico 2010. Rio de Janeiro: Instituto; 2010 [cited 9 Mar 2021]. Available from: https://biblioteca.ibge.gov.br/visualizacao/periodicos/94/cd_2010_religiao_deficiencia.pdf

20. Ministério da Integração Nacional (Brasil). Resolução n 115, de 23 de novembro de 2017. Aprova a Proposição $n^{\circ}$ 113/2017, que acrescenta municípios a relação aprovada pela Resolução CONDEL n 107, e 27 de julho de 2017. Fortaleza: Diário Oficial da União; 2017 [cited 9 Mar 2021]. Available from: https://www.gov.br/sudene/pt-br/ centrais-de-conteudo/resolucao115-23112017-delimitacaodosemiarido-dou-pdf

21. Instituto Brasileiro de Geografia e Estatística (Brasil). Base de dados do estado de Pernambuco: estimativa da população residente (online). Rio de Janeiro: Instituto; 2015. Available from: https://cidades.ibge.gov.br/brasil/pe/ panorama

22. Kepple AW, Segal-Corrêa AM. Conceituando e medindo segurança alimentar e nutricional. Ciênc Saúde Coletiva. 2011 [cited 9 Mar 2021];16:187-99;2011. Available from: http://www.scielo.br/pdf/csc/v16n1/v16n1a22.pdf

23. Silva SC. Insegurança Alimentar e Nutricional em Adultos do Estado de Pernambuco: situação e fatores associados ao acesso à alimentação [Tese]. Recife: Universidade Federal de Pernambuco; 2019.

24. Palmeira PA, Salles-Costa R, Pérez-Escamilla R. Effects of family income and conditional cash transfers on household food insecurity: evidence from a longitudinal study in Northeast Brazil. Public Health Nutrition. 2019;23:756-67. https://doi.org/10.1017/\$1368980019003136

25. Lignani JB, Palmeira PA, Antunes MML, Salles-Costa R. Relationship between social indicators and food insecurity: a systematic review. Rev Bras Epidemiol. 2020;23:e200068. https://doi.org/10.1590/1980-549720200068

26. Fachinni LA, Nunes BP, Motta JVS, Tomasi E, Silva SM, Thumé E, et al. Insegurança alimentar no Nordeste e Sul do Brasil: magnitude, fatores associados e padrões de renda per capita para redução das iniquidades. Cad Saúde Pública. 2014;30:161-74. https://doi.org/10.1590/0102-311X00036013 
27. Instituto Brasileiro de Geografia e Estatística (Brasil). Pesquisa de Orçamentos Familiares 2017-2018: primeiros resultados. Rio de Janeiro: Instituto; 2019 [cited 9 Mar 2020]. Available from: https://biblioteca.ibge.gov.br/ visualizacao/livros/liv101670.pdf

28. Anschau FR, Matsuo T, Segall-Correa AM. Insegurança alimentar entre beneficiários de programas de transferência de renda. Rev Nutr. 2012;25:177-89. https://doi.org/10.1590/S1415-52732012000200001

29. Bezerra TA, Olinda RA, Pedraza DF. Insegurança alimentar no Brasil segundo diferentes cenários sociodemográficos. Ciênc Saúde Colet. 2017;22:637-51. https://doi.org/10.1590/1413-81232017222.19952015

30. Instituto Brasileiro de Geografia e Estatística (Brasil). Pesquisa Nacional por Amostra de Domicílios (PNAD) 2015. Rio de Janeiro: Instituto; 2016 [cited 9 Mar 2021]. Available from: https://biblioteca.ibge.gov.br/visualizacao/livros/ liv98887.pdf

31. Oliveira DS, Demetrio F, Soares MD, Henrique FCS, Amparo-Santos L. Prevalência e fatores associados à insegurança alimentar. Rev Bai Saúde Pública. 2017;41:561-79. https://doi.org/10.22278/2318-2660.2017.v41.n3.a2380

32. Almeida AJ, Santos AS, Nascimento MAO, Oliveira JVC, Silva DG, Mendes-Netto RS. Fatores associados ao risco de insegurança alimentar e nutricional em famílias de assentamentos rurais. Cienc Saúde Coletiva. 2017;22:479-88. https://doi.org/10.1590/1413-81232017222.27102015

33. Silva WM, Mira F. Agricultura familiar e segurança alimentar em comunidades quilombolas do semiárido alagoano. Rev Geo Sertões. 2016;1:60-79. http://revistas.ufcg.edu.br/cfp/index.php/geosertoes/index

34. Drysdale RE, Bob U, Moshabela M. Socio-economic determinants of increasing household food insecurity during and after a drought in the district of iLembe, South Africa, Eco Food Nutr. 2020;60:25-43. https://doi.org/10.1080/ 03670244.2020 .1783663

35. Twongyirwea R, Mfitumukiza D, Barasa B, Naggayu BR, Odongo H, Nyakato V. et al. Perceived effects of drought on household food security in South-western Uganda: Coping responses and determinants. Weather Climate Extr. 2020;24:100201. https://doi.org/10.1016/j.wace.2019.100201

36. Costa JM, Vital TV. Programa de Aquisição de Alimentos: uma análise incremental no período de 2003 a 2016. Rev Inter. 2018 [cited 9 Mar 2021];15:5-23. Available from: https://ojs.ccsa.ufrn.br/index.php/interface/article/view/851

37. Silva J, Souza NGM, Maia JM, Silva JB, Melo AS. Políticas públicas voltadas para a agricultura familiar no semiárido brasileiro. Bio Farm. 2016;12:3. http://revista.uepb.edu.br/index.php/biofarm/article/view/3213/1815

38. Maciel HM, Khan AS. Programa de Aquisição de Alimentos (PAA-LEITE) e seus Beneficiários: uma Análise Multivariada. Percurso Acadêmico. 2016;6:22-41. https://doi.org/10.5752/P.2236-0603.2016v6n11p22

39. Diniz PCO, Lima JRT. Mobilização social e ação coletiva no Semiárido Brasileiro: convivência, agroecologia e sustentabilidade. Redes. 2017;22:189-207. https://doi.org/10.17058/redes.v22i2.9353

40. Vasconcelos FAG, Machado ML, Medeiros MAT, Neves JA, Recine E, Pasquim EM. Public policies of food and nutrition in Brazil: From Lula to Temer. Rev. Nutr. 2019;32(e180161):1-13. https://doi.org/10.1590/1678-9865201932e180161

41. Recine E, Fagundes A, Silva BL, Garcia GS, Ribeiro RCL, Gabriel CG. Reflections on the Extinction of the National Council for Food and Nutrition Security and the Confrontation of Covid-19 in Brazil. Rev Nutr. 2020;33:e200176:17. https://doi.org/10.1590/1678-9865202033e200176

42. Castro IRR. A extinção do Conselho Nacional de Segurança Alimentar e Nutricional e a agenda de alimentação e nutrição. Cad Saúde Pública. 2019;35:e00009919. https://doi.org/10.1590/0102-311X00009919

43. Aguiar LC, DelGrossi ME, Oliveira LG, Ávila ML. As políticas públicas no semiárido brasileiro: uma revisão de literatura. Rev Econ NE. 2019;50(2):9-22.

44. Sandstrom S, Juhola S. Continue to blame it on the rain? Conceptualization of drought and failure of food systems in the Greater Horn of Africa. Environmental Hazards. 2017;16:71-91 https://doi.org/10.1080/17477891.2016.1229656

45. Ministério do Desenvolvimento Social e Combate à Fome (Brasil). Guia de Políticas e Programas Brasília: Ministério; 2011 [cited 9 Mar 2021]. Available from: http://www.cib.pr.gov.br/sites/cib/arquivos_restritos/files/migrados/File/ CIBPR/GUIA_DE_POLITICAS_E_PROGRAMAS_DO_MDS.pdf

46. Ministério do Desenvolvimento Social Agrário (Brasil). Guia de Políticas e Programas. Brasília: Ministério; 2017 [cited 9 Mar 2021]. http://www.mds.gov.br/webarquivos/pecas_publicitarias/banner/_guiadepoliticas_MDSA_online.pdf

47. Bianchini V. Vinte Anos do PRONAF, 1995-2015. Avanços e Desafios. Brasília: Ministério do Desenvolvimento Agrário 2015 [cited 9 Mar 2021]. Available from: http://atividaderural.com.br/artigos/568ba26e514e2.pdf 